\title{
Do business administration studies offer better preparation for supervisory positions than traditional economics studies?
}

Citation for published version (APA):

Heijke, J. A. M., Ramaekers, G. W. M., \& Ris, C. J. (2005). Do business administration studies offer better preparation for supervisory positions than traditional economics studies? Education Economics, 13(3), 315-329. https://doi.org/10.1080/09645290500073829

Document status and date:

Published: 01/01/2005

DOI:

10.1080/09645290500073829

Document Version:

Publisher's PDF, also known as Version of record

Please check the document version of this publication:

- A submitted manuscript is the version of the article upon submission and before peer-review. There can be important differences between the submitted version and the official published version of record.

People interested in the research are advised to contact the author for the final version of the publication, or visit the DOI to the publisher's website.

- The final author version and the galley proof are versions of the publication after peer review.

- The final published version features the final layout of the paper including the volume, issue and page numbers.

Link to publication

\footnotetext{
General rights rights.

- You may freely distribute the URL identifying the publication in the public portal. please follow below link for the End User Agreement:

www.umlib.nl/taverne-license

Take down policy

If you believe that this document breaches copyright please contact us at:

repository@maastrichtuniversity.nl

providing details and we will investigate your claim.
}

Copyright and moral rights for the publications made accessible in the public portal are retained by the authors and/or other copyright owners and it is a condition of accessing publications that users recognise and abide by the legal requirements associated with these

- Users may download and print one copy of any publication from the public portal for the purpose of private study or research.

- You may not further distribute the material or use it for any profit-making activity or commercial gain

If the publication is distributed under the terms of Article 25fa of the Dutch Copyright Act, indicated by the "Taverne" license above, 


\title{
Do Business Administration Studies Offer Better Preparation for Supervisory Positions than Traditional Economics Studies?
}

\author{
HANS HEIJKE*, GER RAMAEKERS* and CATHERINE RIS** \\ ${ }^{*}$ Maastricht University, Maastricht, the Netherlands, ${ }^{* *}$ University of New Caledonia, Noumea and \\ University of Saint-Etienne, France
}

\begin{abstract}
The central theme of the paper is the question of whether graduates of business administration (BA) are better prepared for supervisory positions than non-BA economics graduates and consequently have a greater chance of acquiring supervisory positions and, when they have such positions, earn more. In order to answer this question, we use a data-set that relates to the labour market position of graduates from Dutch universities at the early stages of their careers.

We find that BA graduates, despite their multidisciplinary education and the fact that they perceive fewer deficiencies in their education with respect to the ability for teamwork than non-BA graduates, do not have a greater chance of acquiring supervisory positions than graduates from non-BA economics courses. We also find that earnings in supervisory positions do not differ significantly between BA graduates and non-BA graduates. The finding that most of the skills required for supervisory positions are acquired through work and not in education suggests that a combination of working and learning may be more effective for developing supervisory skills than a purely educational setting.
\end{abstract}

KEY WORDS: Business administration; graduates; supervisory positions; required competences; job chances; earnings

\section{Introduction}

During the past few decades, there has been a growing need for university graduates who are properly prepared for management positions in our postindustrial economy with its global competition. This need for competent managers was illustrated by Quinn et al. (1990, p. v), who stated that 'Modern organizations, as never before, and even at the lowest levels, are in need of

Correspondence Address: Hans Heijke, Research Centre for Education and the Labour Market (ROA), Maastricht University, PO Box 616, 6200 MD Maastricht, the Netherlands. Email: h.heijke@roa.unimaas.nl

Earlier versions of this paper were presented at the 4th ILM Conference, Aberdeen, 11-12 December 2000, and at the 13th EALE Conference, University of Jyväskylä, 13-16 September 2001 
competent managerial leaders. They want technical ability but they also want more. They want people who can survive and help the organization prosper in a world of constant change and intense competition. This means both technical competence and interpersonal excellence. Management is both a technical and a social enterprise'.

Universities responded to the need for graduates who are properly prepared for management positions by starting a variety of graduate and postgraduate courses. These courses have, with reference to the earlier quotation, a multidisciplinary character with an emphasis on economic, technical or social sciences. In particular, economically oriented courses (business administration) became very popular when companies, after recovering from the oil crises in the 1970s, began to have an almost magnetic appeal to students. In the Netherlands, an increasing number of students chose these economics courses, hoping for a dashing career in corporate business.

In this paper, we want to describe to what extent these expectations have been justified and mesh with real life after graduation. We will focus on economically oriented courses that are aimed at preparing graduates for managerial leadership. These multidisciplinary courses have been grouped together under the heading business administration (BA). In the analysis, BA courses will be compared with economics courses that have a more monodisciplinary orientation. The latter include economics, econometrics and business informatics. For the sake of convenience, the latter courses will be referred to in this paper as 'non-BA'.

Based on the situation 1.5 years after graduation, this paper investigates the first step in the careers of economics graduates. We examine which competences are required in supervisory positions of young economists, and where these competences are acquired. We also examine whether graduates working as supervisors experience deficiencies in this field. We are particularly interested in finding out whether BA graduates are better prepared for supervisory positions than their colleagues from non-BA economics courses. In addition, we will examine whether BA graduates have a greater chance of obtaining supervisory positions than non-BA graduates, and whether earnings in supervisory positions are higher with an educational background in BA.

A data-set of economics graduates from four Dutch universities was used for the analysis. The data relate to the labour market position of graduates 18 months after graduation (i.e., to the early stages of their careers). This data-set contains detailed information that allows us to analyse which graduates made the fastest and most successful start on the long way to the top. ${ }^{1}$

The paper continues in the next section with a description of the data used. The third section examines the competences required of graduates who work as supervisors, and whether these competences were predominantly acquired through education or through work, or otherwise. After having established the competences that are required of supervisors, the fourth section addresses the issue of educating for supervisory positions by examining deficiencies in education with respect to the competences that are important for supervisors. The issue here is whether BA provides better preparation than non-BA economics courses. The subsequent section then examines which characteristics of economics graduates-including their major (BA versus non-BA) - influence the graduates' odds of acquiring supervisory positions and the earnings in such positions. In the penultimate section, we discuss the empirical results. Finally, the seventh section contains a summary of our conclusions. 


\section{The Data}

The data used here were obtained from the annual, nationwide postal surveys among graduated masters from all universities in the Netherlands. ${ }^{2}$ The surveys are held approximately 18 months after graduation. In this paper, we used data obtained from the survey carried out at the end of 1999 among all graduates from the 1997/98 academic year and the survey carried out at the end of 2000 among all graduates from the 1998/99 academic year. The response rate in both surveys was $46 \%$. This paper covers economics graduates from only four Dutch universities. The reason is that of the six Dutch universities with economics faculties, only four use the extensive version of the questionnaire, which also contains questions about competences. All four universities included in our data-set offer non-BA economics courses, whereas BA can only be studied at three of these four universities. It should be mentioned that in the Netherlands university education is highly standardized, and differences in labour market effects between institutions of higher education are not found in the tight labour market situation of 1999 and 2000.

Our sample of 1323 graduates with paid jobs (working at least 12 hours per week) consists of 239 BA graduates (18\%) and 1084 non-BA graduates (82\%). Table 1 presents their characteristics. For a definition of the variables, see Appendix 1.

Table 1. Characteristics of BA graduates and non-BA graduates, used in the estimates

\begin{tabular}{lllc}
\hline & $\begin{array}{c}\text { BA } \\
\text { graduates }\end{array}$ & $\begin{array}{c}\text { Non-BA } \\
\text { graduates }\end{array}$ & Total \\
\hline Personal characteristics & & & \\
$\quad$ Average age (years) & $26.5(239)$ & $26.2(1084)$ & $26.3(1323)$ \\
$\quad$ Gender: male & $64 \%(153)$ & $71 \%(773)$ & $70 \%(926)$ \\
Year of survey: 2000 & $59 \%(140)$ & $46 \%(498)$ & $48 \%(638)$ \\
Experience & & & \\
$\quad$ Study/internship experience & $3 \%(7)$ & $25 \%(269)$ & $21 \%(276)$ \\
$\quad$ No experience (reference) & $44 \%(104)$ & $44 \%(471)$ & $44 \%(575)$ \\
$\quad$ Only domestic internship experience & $54 \%(128)$ & $32 \%(344)$ & $36 \%(472)$ \\
$\quad$ Also) international study/internship experience & $49 \%(116)$ & $46 \%(497)$ & $46 \%(613)$ \\
$\quad$ Relevant work experience & $63 \%(150)$ & $54 \%(581)$ & $55 \%(731)$ \\
$\quad$ Committee experience & $38 \%(91)$ & $36 \%(393)$ & $37 \%(484)$ \\
$\quad$ Change of job after graduation & $15.2(239)$ & $16.9(1084)$ & $16.5(1323)$ \\
$\quad$ Average current job tenure (months) & $41 \%(99)$ & $40 \%(433)$ & $40 \%(532)$ \\
Job found through network & & & \\
Job characteristics & $29 \%(69)$ & $27 \%(287)$ & $27 \%(356)$ \\
$\quad$ Supervisory position & $64 \%(152)$ & $63 \%(687)$ & $63 \%(839)$ \\
Job at university level & $62 \%(148)$ & $73 \%(795)$ & $71 \%(943)$ \\
$\quad$ Job in own domain: & $13.66(239)$ & $13.10(1084)$ & $13.21(1323)$ \\
$\quad$ Average gross hourly wages (€) & & & \\
Organization characteristics & $85 \%(202)$ & $84 \%(907)$ & $84 \%(1109)$ \\
$\quad$ Large organization & $93 \%(222)$ & $89 \%(968)$ & $90 \%(1190)$ \\
$\quad$ Private sector & &
\end{tabular}

Total number of cases in the analysis, 1323. Standard deviations: age, 2.2; job tenure, 13.2; wage, 3.54. 
Table 1 shows that more than one-quarter (27\%) of the graduates had a supervisory position. The majority of the respondents was male and, on average, 26 years old at the time of the survey. Apart from their formal qualification (their university education), many graduates gained additional, informal qualifications before or during their economics study, in the form of experience in a management committee, (international) internship experience or work experience that is relevant for their field of study. At the time of the survey, the majority of graduates in paid jobs had a job that matched their educational level and a job that matched their field of education. They earned on average $€ 13$ gross per hour. The vast majority was employed in large organizations (with over 100 employees) and in the private sector. On average, they had been working for their current employer for 16 months.

Compared with the non-BA graduates, BA graduates were more often female, were more strongly represented in the 2000 survey, had more experience (they had more often gained international study/internship experience and committee experience before or during their economics study), worked less often in their own educational domain, and earned higher hourly wages.

\section{Required Competences for Supervisory Positions}

In this section we pay attention to the empirical evidence found in our data-set on the competences that are required for supervisory positions, held by recently graduated economics masters. For this aim, we focus on differences between supervisory and non-supervisory positions with respect to the importance of various competences. This part of the paper concludes with the question of whether competences required for supervisory positions are acquired predominantly through initial education, through work, or through other means.

The survey contains a list of 14 competences that represent demands for knowledge and skills. The graduated masters could indicate for each competence to what degree they made use of that particular competence in their current job. The intensity of use was measured on a five-point scale, ranging from 1 ('do not use') to 5 ('use to a high degree').

For graduates working both in supervisory positions and in non-supervisory positions, Table 2 presents the intensity of use of the 14 competences. For each competence, the table contains the percentage share of recently graduated economics masters who stated that they used that particular competence to a high degree.

The figures in Table 2 show that leadership, initiative, planning and organizing, creativity, taking advantage of change, communicative skills, teamwork, and the ability to work independently are more important for economics graduates working in supervisory positions than for economics graduates working in nonsupervisory positions.

Not only from our empirical results, but also from literature on management, we find evidence of the importance of these competences for supervisors. Quinn et al. (1990) for instance distinguish eight roles of managerial leaders. According to Quinn et al. (1990, p. 21) taking initiative is required for the 'director role', planning and organizing for the 'coordinator role', creativity and taking advantage of change for the 'innovator role', communicative skills for the 'mentor role', and teamwork for the 'facilitator role' of managerial leaders. Milter and Stinson (1995, p. 35) stress the importance for managerial leaders of among others the ability to 
Table 2. Use (to a high degree) of competences in supervisory and nonsupervisory positions

\begin{tabular}{|c|c|c|}
\hline Competence & Supervisory positions & Non-supervisory positions \\
\hline Discipline-specific knowledge & $29 \%$ & $30 \%$ \\
\hline Discipline-specific methods and techniques & $25 \%$ & $27 \%$ \\
\hline Computer use & $50 \%$ & $52 \%$ \\
\hline Leadership & $22 \% * *$ & $3 \%$ \\
\hline Initiative & $39 \% * *$ & $29 \%$ \\
\hline Independence & $52 \% * *$ & $44 \%$ \\
\hline Planning and organizing & $40 \% * *$ & $28 \%$ \\
\hline Numeracy & $43 \%$ & $43 \%$ \\
\hline Accuracy & $36 \%$ & $39 \%$ \\
\hline Communication skills & $52 \% * *$ & $43 \%$ \\
\hline Teamwork & $40 \% * *$ & $30 \%$ \\
\hline Creativity & $23 \% * *$ & $17 \%$ \\
\hline Taking advantage of change & $39 \% * *$ & $30 \%$ \\
\hline International orientation & $20 \%$ & $17 \%$ \\
\hline
\end{tabular}

Significant differences are bold: ${ }^{*}$ difference is significant at $5 \%$ level, ${ }^{* *}$ difference is significant at $1 \%$ level.

work independently. Whetten and Cameron (1995) emphasize the importance of personal skills (such as creativity), interpersonal skills (such as communicative skills), and group skills (such as teamwork) for effective managers.

\section{Sources of Competences}

From Table 2 we see that eight competences are significantly more important in supervisory positions than in non-supervisory positions; namely, leadership skills, initiative, independence, planning and organizing, communication skills, teamwork, creativity, and taking advantage of change. It is interesting to see where these competences are predominantly acquired. Table 3 shows where graduates who work as supervisors predominantly acquired these important competences: in education, through work, or by other means. The figures show that the skills relating to leadership, planning and organizing, communication, and taking advantage of change are acquired most often in the workplace. Initiative is most often acquired outside education (work and otherwise), while creativity is usually acquired neither in education nor through work. The ability to work as a member of a team is most often acquired in education by BA graduates and in the workplace by non-BA graduates. This means that of the eight competences that are relatively important for supervisors, only teamwork is predominantly acquired in education (and only by BA graduates). This is in line with McCall et al. (1988), who found that most of the development of management skills takes place on the job, and not in seminars, classrooms, or MBA programmes.

As already mentioned, BA graduates acquire the ability to work as a member of a team most often in education, while non-BA graduates acquire this ability most often in the workplace. Although both BA graduates and non-BA graduates acquire planning and organizing competences most often in the workplace, BA graduates acquire these competences more often in education than non-BA 
Table 3. Sources where supervisors predominantly acquire the competences that are of specific importance for them

\begin{tabular}{|c|c|c|c|c|}
\hline & Education & Work & Otherwise & Not applicable \\
\hline \multicolumn{5}{|l|}{ Leadership } \\
\hline BA & $9 \%$ & $68 \%$ & $24 \%$ & $0 \%$ \\
\hline Non-BA & $7 \%$ & $69 \%$ & $21 \%$ & $4 \%$ \\
\hline \multicolumn{5}{|l|}{ Initiative } \\
\hline BA & $11 \%$ & $42 \%$ & $43 \%$ & $4 \%$ \\
\hline Non-BA & $12 \%$ & $41 \%$ & $45 \%$ & $3 \%$ \\
\hline \multicolumn{5}{|c|}{ Independence } \\
\hline BA & $37 \%$ & $30 \%$ & $32 \%$ & $1 \%$ \\
\hline Non-BA & $43 \%$ & $24 \%$ & $32 \%$ & $1 \%$ \\
\hline \multicolumn{5}{|c|}{ Planning and organizing* } \\
\hline BA & $33 \%$ & $47 \%$ & $19 \%$ & $1 \%$ \\
\hline Non-BA & $21 \%$ & $57 \%$ & $21 \%$ & $2 \%$ \\
\hline \multicolumn{5}{|c|}{ Communication skills } \\
\hline BA & $20 \%$ & $49 \%$ & $30 \%$ & $1 \%$ \\
\hline Non-BA & $20 \%$ & $44 \%$ & $36 \%$ & $1 \%$ \\
\hline \multicolumn{5}{|c|}{ Teamwork** } \\
\hline BA & $58 \%$ & $25 \%$ & $18 \%$ & $0 \%$ \\
\hline Non-BA & $31 \%$ & $43 \%$ & $24 \%$ & $2 \%$ \\
\hline \multicolumn{5}{|l|}{ Creativity } \\
\hline $\mathrm{BA}$ & $15 \%$ & $30 \%$ & $52 \%$ & $4 \%$ \\
\hline Non-BA & $13 \%$ & $30 \%$ & $51 \%$ & $7 \%$ \\
\hline \multicolumn{5}{|c|}{ Taking advantage of change } \\
\hline BA & $15 \%$ & $50 \%$ & $33 \%$ & $3 \%$ \\
\hline Non-BA & $8 \%$ & $55 \%$ & $31 \%$ & $6 \%$ \\
\hline
\end{tabular}

* Difference between BA graduates and non-BA graduates is significant at $5 \%$ level,

** difference between BA graduates and non-BA graduates is significant at $1 \%$ level.

graduates. As for the other six competences that are relatively important for supervisors, no significant differences between BA graduates and non-BA graduates were found with respect to education as the primary source of acquisition.

\section{Deficiencies in Education}

Because the data do not contain information on competences acquired by the graduates, the issue of educating for supervisory positions is addressed in this section by looking at the deficiencies in education with respect to the eight competences that are crucial for supervisory positions, as experienced by graduates who work as supervisors. In the penultimate section (Estimation Results), this issue will be addressed by estimating the effect of the educational major, BA or non-BA, on the probability of acquiring a supervisory position.

In the questionnaire, respondents could indicate up to three competences from the list of 14 competences that they regarded as having received too little attention in their education. Table 4 shows, for each competence that is particularly important in supervisory positions, the percentage of BA and non-BA graduates working as supervisors who indicated that it received insufficient attention in education. As can be seen in Table 4, education performs especially poor in the 
Table 4. Insufficient attention paid in education to supervisory competences, according to supervisors

\begin{tabular}{lrc}
\hline & BA & Non-BA \\
\hline Leadership & $56 \%$ & $47 \%$ \\
Initiative & $13 \%$ & $16 \%$ \\
Independence** $^{*} \%$ & $1 \%$ \\
Planning and organizing $_{\text {Communication skills }}$ & $8 \%$ & $28 \%$ \\
Teamwork* & $37 \%$ & $49 \%$ \\
Creativity & $3 \%$ & $18 \%$ \\
Taking advantage of change & $31 \%$ & $26 \%$ \\
\hline
\end{tabular}

* Difference between BA graduates and non-BA graduates is significant at $5 \%$ level,

** difference between BA graduates and non-BA graduates is significant at $1 \%$ level.

eyes of the supervisors with respect to leadership skills and communicative skills. In short, education does not fully succeed in teaching competences that are important for supervisory positions (at least according to the graduates who work as supervisors). Perhaps this is why the supervisory competences are most often acquired outside education (Table 3). It should be mentioned, however, that graduates believe that supervisory skills are learnable in education.

As we have seen in Table 3, BA graduates who work as supervisors acquire the ability to work as a member of a team and planning and organizing competences significantly more often in education than non-BA graduates who work as supervisors. One may therefore expect that, within the population of supervisors, BA graduates experienced fewer deficiencies in their education than non-BA graduates, at least with respect to these particular competences.

Table 4 shows that in supervisory positions BA graduates indeed indicated less often than non-BA graduates that their education paid insufficient attention to the ability to work as a member of a team. BA graduates also indicated less often (although not significantly) than non-BA graduates that their education paid insufficient attention to planning and organizing skills. On the other hand, BA graduates indicated more often than other graduates that their education paid insufficient attention to the ability to work independently. This is in line with the finding in Table 3 that BA graduates acquire this competence less often (although not significantly) in education than non-BA graduates. As for the other five supervisory competences, no clear differences between BA graduates and the other graduates were found in this respect. In short, on the basis of the deficiencies experienced in education with respect to the eight competences that are crucial for supervisory positions, no clear conclusion can be derived on which study offers the best preparation for supervisory jobs. At the very most it can be said that for two of the eight competences that are crucial for supervisory positions, as far as education plays a role in developing them, BA graduates seem better prepared (planning and organizing, however insignificantly, and teamwork), and that for one of these competences non-BA graduates seem better prepared (ability to work independently).

In the following sections we estimate whether BA graduates or non-BA graduates have the best odds to get supervisory jobs and the highest earnings in these jobs. 


\section{Which Economics Graduates Obtain Supervisory Positions and Have the Highest Earnings?}

In explaining wage differences between people with different educational backgrounds, the interaction between the characteristics of an individual and the characteristics of the job proves to be crucial (Hartog, 1985 ; and for economists, Heijke and Koeslag, 1999). It is the job-matching theory that emphasizes this interaction. ${ }^{3}$ Given the job, the degree to which the qualifications acquired by the worker match the qualifications required in the job determines the worker's performance-or productivity-and hence his/her wages in that job. The job-matching theory thus shows how individuals are allocated to jobs that require varying qualifications on the basis of the qualifications that they possess. By utilizing their knowledge and skills where these will generate the relatively highest productive output, comparative advantages can be achieved. From the human capital theory, it should be added that persons can increase their capabilities to perform in certain jobs by investing in training and through experience. ${ }^{4}$

With regard to supervisory positions, the literature on management indicates that managerial leadership requires a holistic understanding of business and a number of behavioural skills. Milter and Stinson (1995, pp. 30-38) argue that continuous innovation is essential for organizations in a competitive society. In this respect, they see a holistic perspective as the most defining structural characteristic of organizations. This implies that managerial leaders should be organizationally oriented instead of functionally oriented, which means that they need an understanding of the whole (vision, mission, goals and strategy) and their place within the organizational processes. In other words, they need to have a holistic understanding of the business and of the environment in which the business functions. BA courses, which at least in the Netherlands has a more multidisciplinary orientation-and hence provides a more holistic view on business and its environment-than the mono-disciplinary non-BA economics courses, should therefore constitute a more appropriate education for supervisory positions than non-BA economics courses. In line with the job-matching theory, one might therefore expect these BA graduates with their multidisciplinary education to have a comparative advantage over the non-BA graduates with their monodisciplinary education, at least in supervisory positions that require a holistic understanding of business. For this reason it may be expected that BA students probably have greater odds to obtain supervisory positions than students graduated from non-BA economics courses. As for the required behavioural skills, we expect that, in line with the job-matching theory, older and more experienced graduates have the best cards for being selected for supervisory positions.

If we look at how these competences are rewarded, there are several explanations why-in addition to the matching effect explained earlier-a supervisory position should be better paid. One explanation within the framework of the internal labour market theory is that 'managers' salaries are structured to provide incentives to lower-level executives to work hard while competing for high-level jobs' (Hamermesh and Rees, 1984, p. 352). For instance, the high earnings of a top executive are often the reward for hard work in the past that has shown the corporation's board that the executive is marginally more productive than others (Lazear and Rosen, 1981). 
Another explanation for higher earnings in supervisory positions can be found in the hierarchical theory of organization. According to this theory, the salary structure is arranged to reflect the responsibilities required at each level of management. It is argued that the salary is related to the responsibility of the job rather than to the ability of the individual (Lydall, 1968). Hamermesh and Rees (1984, pp. 353-354) opposed the hierarchical theory of organization. They argued that supervisory positions are better paid because the higher ability, work effort and willingness to take risks of the individual are rewarded.

Within the general framework already outlined, we examine whether BA graduates or non-BA economics graduates have the best odds for acquiring supervisory positions and subsequently have the highest earnings in these jobs. We use a wage model that allows us to take into account that the influences of individual characteristics on the wages in supervisory and non-supervisory positions are different.

The wage model takes the following form: ${ }^{5}$

$\begin{aligned} \text { In } w_{i, s} & =\theta_{s}^{\prime} X_{i}+e_{i, s} \\ \operatorname{In} w_{i, n s} & =\theta_{n s}^{\prime} X_{i}+e_{i, n s}\end{aligned}$

where $w_{i, s}$ and $w_{i, n s}$ is the natural logarithm of the gross hourly wage of individual $i$ in a supervisory position and in a non-supervisory position, $X_{i}$ is a vector of the individual characteristics (e.g., education [BA versus non-BA], age, or experience) that determine wages, and $e_{i, s}$ and $e_{i, n s}$ are error terms with the usual characteristics. This model is estimated in a first round.

However, there may be selection in the way in which graduates are assigned to jobs. If unobservable individual characteristics, which determine the kind of job a graduate will be assigned to, are the same as characteristics that determine the wages, then estimations from these two subsamples will be biased. To correct for this bias, Heckman (1979) and Lee (1978) suggested a two-step procedure, which we will apply in a second estimation round. In this round, we first estimate the probability for a graduate to obtain a supervisory position by means of a logistic regression analysis; and second we introduce the Inverse Mill's Ratio (Lambda), derived from the logit estimation, as an additional explanatory variable in the wage equations (see Lee, 1983). This method produces a test for the selection of graduates among jobs. To assure identification, we need at least one variable that affects the allocation over supervisory and non-supervisory positions but not the wage. The variable 'job found through network' fulfils this criterion. Finally, the model we estimate is:

$$
\begin{aligned}
\text { In } w_{i, s} & =\theta_{s}^{\prime} X_{i}+e_{i, s} \\
\text { In } w_{i, n s} & =\theta_{n s}^{\prime} X_{i}+e_{i, n s} \\
I_{i}^{*} & =\gamma^{\prime} Z_{i}+v_{i}
\end{aligned}
$$

with $I_{i}^{*}$ being the latent variable; if $I_{i}^{*}>0$, graduate $i$ works as a supervisor; if $I_{i}^{*}<$ 0 , he/she works in a non-supervisory position. $Z_{i}$ is a vector of individual characteristics that influence the probability of obtaining a supervisory position, such as variables referring to person, education, experience, job and the organization in which one works. 


\section{Estimation Results}

Table 5 first presents the results on obtaining a supervisory position, distinguishing between BA and non-BA graduates. As personal characteristics, we include two variables in the analysis; namely, gender and age. Five variables are used to indicate the experience of graduates; namely, study/internship experience, relevant work experience, committee experience, job mobility and current job tenure. One variable is introduced as a proxy for a graduate's social capital; namely, whether or not he/she acquired his/her job through (a network of) personal contacts (teachers, previous internships, previous open meetings with employers, previous jobs, internal vacancies, family, friends, acquaintances). Finally, two characteristics of the organizations in which graduates work are included in the analysis; namely, size and economic sector.

The results in Table 5 show that, contrary to expectations, education (BA versus non-BA) does not seem to play a role in obtaining a supervisory position. The results also indicate, however, that experience-whether acquired through work or a management committee before or during the university education-increases the chances of obtaining a supervisory position. These chances increase with the length of time that graduates have been working in their current jobs. The results also show that male graduates have better odds of being supervisors than female graduates. Moreover, graduates who work in the private sector have better odds

Table 5. Logistic regression analysis of the graduates' odds of acquiring a supervisory position

\begin{tabular}{lcc}
\hline & Coefficient & Standard error \\
\hline Personal characteristics & & \\
Gender: male & $0.332^{*}$ & 0.150 \\
Age (years) & 0.050 & 0.032 \\
Major: BA & 0.172 & 0.172 \\
Experience & & \\
Study/internship experience & & \\
$\quad$ No experience (reference) & & 0.177 \\
$\quad$ Only domestic internship experience & -0.109 & 0.189 \\
$\quad$ (Also) international study/internship experience & -0.096 & 0.133 \\
Relevant work experience & $0.377^{* *}$ & 0.137 \\
Committee experience & $0.439^{* *}$ & 0.160 \\
Change of job after graduation & 0.072 & 0.008 \\
Current job tenure (months) & $0.046^{* *}$ & 0.135 \\
Job found through network & $0.276^{*}$ & \\
Organization characteristics & & 0.176 \\
$\quad$ Large organization & -0.191 & 0.252 \\
Private sector & $0.596^{*}$ & 0.132 \\
Year of survey: 2000 & -0.185 & 0.884 \\
Constant & $-4.182^{* *}$ & 1419.33 \\
-2 log-likelihood & & $121.56^{* *}$ \\
Chi-square & & 1323 \\
Number of cases & & \\
\hline
\end{tabular}

*Significant at the $5 \%$ level,

** significant at the $1 \%$ level. 
of obtaining supervisory positions than graduates who work in the public sector. Finally, networks of personal contacts increase the chances of obtaining supervisory positions.

In order to find out how BA graduates and non-BA graduates are paid in supervisory and non-supervisory positions, the wage model is estimated with and without correction for selectivity. In line with the framework outlined in the previous section, talent, education and experience are expected to determine wages. In view of this reasoning, age and the variables referring to investment in human capital through experience (study/internship experience, relevant work experience, committee experience, job mobility and current job tenure) are expected to have a positive effect on wages.

Furthermore, in line with the job matching considerations presented in the previous section, we expect that graduates with jobs that match their educational level and educational domain are more productive and hence earn higher wages than graduates with jobs that do not match their education.

The results of the estimates without and with correction for selectivity are presented in Table 6 for, respectively, the supervisory and non-supervisory positions. Within supervisory positions BA graduates do not earn significant higher wages, which indicates that they do not have a comparative advantage over graduates with a major in non-BA economics courses in these jobs. In non-supervisory positions, however, BA graduates do earn higher wages than non-BA graduates. It seems that within these jobs, which are 'lower wage jobs', they obtain a better position than non-BA graduates. However, once we have corrected for selectivity, the effect of the major is no longer significant. This result could indicate that unobservable characteristics related to the choice of a BA study are also linked to the chance of being selected for a supervisory position. And then, without correcting for such selection, the impact of BA studies on wages for non-supervisors is overestimated.

Looking at the experience variables, we find that in both supervisory positions and non-supervisory positions wages increase with age, but this effect is higher in supervisory positions. This result suggests that age as a measure of life experience is rewarded better in supervisory positions. We see that relevant work experience, committee experience and job tenure do not influence wages. This results probably from the fact that these variables increase the odds of obtaining a supervisory position, but once one has been selected for a supervisory position these types of experience are no longer rewarded as an extra asset. Experience is important in order to be selected as a supervisor, because it increases managerial competences, but does not as such lead to higher wages. Study or internship experience affects neither the chance of obtaining a supervisory position nor the wages.

Both in supervisory positions and in non-supervisory positions, earnings are higher if the level of the job matches the level of education, but this effect is greater for supervisors. The results also show that working within one's own domain generates higher wages only in non-supervisory positions. Within one's own domain, subject-specific skills are apparently rewarded less for supervisors than for non-supervisory workers.

Moreover, male graduates have better odds of obtaining a supervisory position, but once they have a supervisory position (or a non-supervisory position for that matter) they do not earn higher wages than female managers. The results also show that organization characteristics influence wages for both supervisors and non-supervisors. 


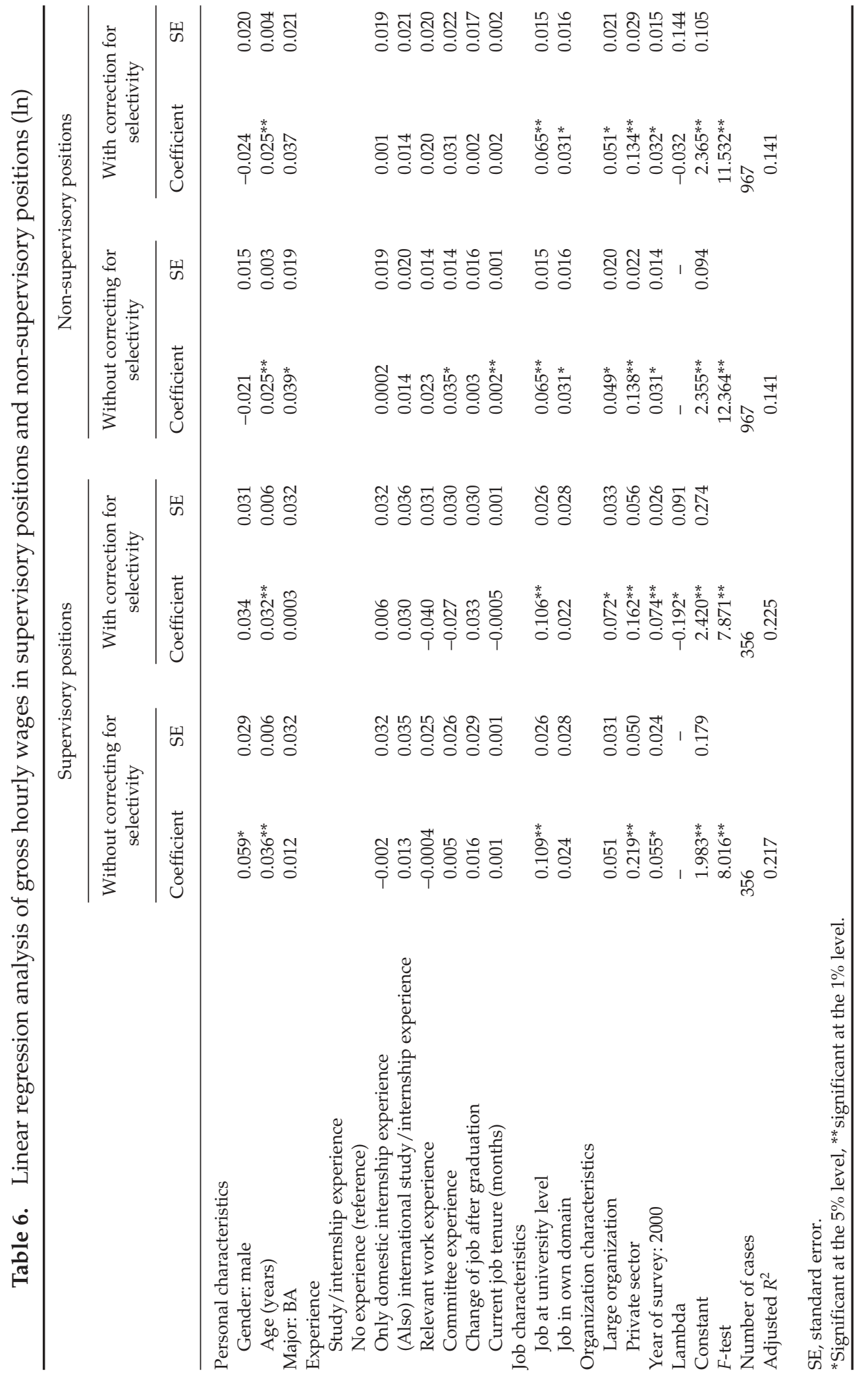


Lambda is introduced to correct for selection bias. In the supervisors' wage equation, its coefficient indicates that characteristics explaining which graduates work in supervisory positions are negatively correlated to unobservable characteristics explaining the wages. ${ }^{6}$ This suggests that graduates who have been selected for supervisory positions earn lower wages than graduates who would be randomly selected for these jobs. An explanation for this result could be that young graduates in supervisory positions need additional training to master the competences required in supervisory positions and share the costs of this training. This result is consistent with the specific sample we used. This sample only covers young graduates who still need to acquire certain competences and whose assignment to a supervisory position is not yet totally efficient.

\section{Conclusion}

We find that economics graduates who work in supervisory positions must have directive competences (leadership skills, taking initiative), coordinative competences (planning and organizing), innovative competences (creativity, taking advantage of change) and human relations competences (communicative skills, teamwork), as well as the capacity to work independently. In order to educate future managerial leaders, universities started BA courses. These multidisciplinary courses with an emphasis on economics have become very appealing to students. In the Netherlands, an increasing number of students choose BA courses, hoping for a dashing career in corporate business. Our research findings, however, indicate that an economics education, including BA, can transmit these competences only to a limited extent. Of the eight competences mentioned earlier, only the ability to work as a member of a team is predominantly acquired in education. This is, however, only the case with BA graduates (non-BA graduates acquire this ability predominantly in the workplace). According to supervisors, the performance of economics programmes is especially poor with respect to leadership skills and communication skills. In short, education does not fully succeed in teaching competences that are important for supervisors. Perhaps this is the reason why these competences are predominantly acquired outside education.

Despite their multidisciplinary education and the fact that they experience significantly fewer deficiencies in their education with respect to teamwork than other graduates, BA graduates do not have better odds of acquiring supervisory positions than graduates of non-BA economics courses. The results also show that once BA graduates have acquired a supervisory position, they do not earn more than non-BA graduates. Obviously, initial BA studies do not provide their graduates with the intended comparative advantages in fulfilling supervisory positions.

It seems very difficult for initial university education to generate the skills that are required for supervisory positions. Since most of these skills are predominantly acquired through work, a combination of working and learning may be more effective. Finally, it should be pointed out that the research findings concern graduates in the very early stage of their careers.

\section{Acknowledgements}

The authors would like to thank Frank Moers of the Faculty of Economics and Business Administration of Maastricht University, and Maarten Wolbers and Andries de Grip of the Research Centre for Education and the Labour Market for 
their comments on an earlier version of this paper. Furthermore, they thank Christoph Meng of the Research Centre for Education and the Labour Market for his contribution to the wage analyses.

\section{Notes}

1. To avoid any distortion resulting from the inclusion of graduates from part-time courses who remain working in the jobs that they already had during their education, only graduates from fulltime courses were analysed.

2. These surveys were carried out by the Research Centre for Education and the Labour Market of Maastricht University.

3. Tinbergen (1956), Sattinger (1975), Jovanovic (1979) and Hartog (1992) made important contributions to the development of the job matching theory. For an overview of this theory, see Sattinger (1993).

4. For a broad outline of the human capital theory, see Schultz (1961) and Becker (1964).

5. See Mincer (1974). We omitted, however, the squared variables in the wage equations because the population consists of young, recently graduated economics masters, who have only been in the labour market for at most 1.5 year.

6. However, lambda is not significant in the non-supervisors' wage equation, which means that the sample of non-supervisors is not different from the population as a whole.

\section{References}

Becker, G. S. (1964) Human Capital: A Theoretical and Empirical Analysis with Special Reference to Education (New York: NBER).

Hamermesh, D. S. and Rees, A. (1984) The Economics of Work and Pay (New York: Harper \& Row).

Hartog, J. (1985) Earnings functions: testing for the demand side, Economic Letters, 19(3), pp. 281-285.

Hartog, J. (1992) Capabilities, Allocation and Earnings (Dordrecht: Kluwer Academic Publishers).

Heckman J. (1979) Sample selection bias as a specification error, Econometrica, 47(1), pp. 153-161.

Heijke, H. and Koeslag, M. (1999) The labour-market position of university education and higher vocational education in economics and business administration: a comparison, Education Economics, 7(3), pp. 259-276.

Jovanovic, B. (1979) Job matching and the theory of turnover, Journal of Political Economy, 87(5), pp. 972-990.

Lazear, E. and Rosen, S. (1981) Rank-order tournaments as optimum labor contracts, Journal of Political Economy, 89, pp. 841-864.

Lee L. F. (1978) Unionism and wage rates: a simultaneous equations model with qualitative and limited dependent variables, International Economic Review, 19(2), pp. 415-433.

Lee, L. F. (1983) Generalized econometric models with selectivity, Econometrics, 51(2), pp. 507-513.

Lydall, H. (1968) The Structure of Earnings (Oxford: Clarendon).

McCall, M. W. et al. (1988) The Lessons of Experience. How Successful Executives Develop on the Job (New York: The Free Press).

Milter, R. G. and Stinson, J. E. (1995) Educating leaders for the new competitive environment, in: W. H. Gijselaers et al. (Eds) Educational Innovation in Economics and Business Administration: The Case of Problem-Based Learning, pp. 30-38 (Dordrecht: Kluwer Academic Publishers).

Mincer, J. (1974) Schooling, Experience and Earnings (New York: Columbia University Press).

Quinn, R. E. et al. (1990) Becoming a Master Manager: A Competence Framezork (New York: John Wiley \& Sons).

Sattinger, M. (1975) Comparative advantage and the distribution of earnings, Econometrica, 43(3), pp. 455-468.

Sattinger, M. (1993) Assignment models of the distribution of earnings, Journal of Economic Literature, 31, pp. 831-880.

Schultz, T. W. (1961) Investment in human capital, The American Economic Review, 11, pp. 1-17.

Tinbergen, J. (1956) On the theory of income distribution, Weltwirtschaftliches Archiv, 77(2), pp. 155-175.

Whetten, D. A. and Cameron, K. S. (1995) Developing Management Skills (New York: HarperCollins College Publishers).

Zavoina, R. and McKelvey, W. (1975) A statistical model for the analysis of ordinal level dependant variables, Journal of Mathematical Sociology, pp. 103-120. 


\section{Appendix 1: Definitions of variables}

\author{
Gross hourly wages \\ Supervisory position \\ Gender: male \\ Age \\ Year of survey: 2000

\section{BA} \\ Study/internship experience \\ No experience
}

Only domestic internship experience

(Also) international study/internship experience

Relevant work experience

Committee experience

Change of job after graduation

Job found through network

Current job tenure

Job at university level

Job in own domain

Large organization

Private sector
Natural logarithm of the gross hourly wages in the current job (measured in Dutch guilders)

Dummy = 1 if the respondent has a job in which he/she supervizes other workers

Dummy $=1$ if the respondent is a man

Age (years) at the time of graduation

Dummy $=1$ if the respondent graduated in the academic year 1998/99

Dummy $=1$ if the respondent graduated in BA

Dummy $=0$ if the respondent did not acquire internship experience or international internship/ study experience during his/her study (reference) Dummy $=1$ if the respondent acquired only internship experience in The Netherlands during his/her study

Dummy = 1 if the respondent acquired (also) study experience or internship experience abroad during his/her study

Dummy = 1 if the respondent has acquired paid or unpaid work experience relevant to the study, before or during his/her study

Dummy = 1 if the respondent has acquired experience on a management committee before or during his/her study

Dummy = 1 if the respondent changed of employer after graduation

Dummy = 1 if the respondent acquired his current job through (a network of) personal contacts

Time (months) that graduates have been employed with current employer

Dummy = 1 if the respondent has a job for which the employer required a university-level education Dummy = 1 if the respondent has a job for which the employer required the respondent's own or a related major

Dummy $=1$ if the respondent works in an organization with more than 100 employees (including branches)

Dummy = 1 if the respondent works in a profitseeking organization 
Copyright of Education Economics is the property of Routledge, Ltd. and its content may not be copied or emailed to multiple sites or posted to a listserv without the copyright holder's express written permission. However, users may print, download, or email articles for individual use. 